3. Воропаев А.Ф. Теория теплообмена рудничного воздуха и горных пород в глубоких шахтах. - М.: Недра, 1966. - С. 219.

4. Шалимов А.В., Кормщиков Д.С., Газизуллин Р.Р., Сёмин М.А. Моделирование динамики тепловых депрессий и ее влияния на проветривание горных выработок // Вестн. ПНИПУ: Геология. Нефтегазовое и горное дело. - 2014. - Т. 13, № 12. - C.41-47. DOI: 10.15593/2224-9923/2014.12.5

5. Казаков Б.П., Шалимов А.В., Сёмин М.А., Гришин Е.Л., Трушкова Н.А. Конвективная стратификация воздушных потоков по сечению горных выработок, ее роль в формировании пожарных тепловых депрессий и влияние на устойчивость проветривания // Горный журнал. - 2014. - №12. - С. 105-109.

6. Соболев С.Л. Уравнения математической физики. - 2-е изд., перераб.- М.; Л.: Гос. изд-во техн.теорет. лит., 1950. - С. 424.

7. Казаков Б.П., Левин Л.Ю., Шалимов А.В. Теория и практика прогнозирования, профилактики и борьбы с аварийными нарушениями проветривания рудников. - М.: ООО «Издательский дом Недра», 2016. - С. 244.

8. Казаков Б.П., Шалимов А.В., Гришин Е.Л. Теплообмен вентиляционного воздуха с крепью воздухоподающего ствола и породным массивом // Физико-технические проблемы разработки полезных ископаемых. - 2011. - № 5. - С. 92-98.

9. Левин Л.Ю., Семин М.А., Зайцев А.В. Численное решение сопряженной задачи теплораспределения в рудничной атмосфере и окружающем породном массиве для сети горных выработок произвольной топологии // Горный информационно-аналитический бюллетень (научно-технический журнал). 2013. - № 8. - С. 176-180.

10. Левин Л.Ю., Семин М.А., Зайцев А.В. Разработка математических методов прогнозирования микроклиматических условий в сети горных выработок произвольной топологии // Физико-технические проблемы разработки полезных ископаемых. - 2014. - № 2. - С. 154-161.

11. Бабина О.И. Сравнительный анализ имитационных и аналитических моделей // Имитационное моделирование. Теория и практика: материалы конф. сб. докл. - СПБ., 2009. - С. 73-77.

УДК 622.831

DOI:10.7242/echo.2020.2.21

\title{
МЕХАНИЗМ ОБРАЗОВАНИЯ ОЧАГОВ ГАЗОДИНАМИЧЕСКИХ ЯВЛЕНИЙ В СКЛАДЧАТЫХ СТРУКТУРАХ КАЛИЙНЫХ ПЛАСТОВ
}

\author{
Е.В. Лукьянец, Д.А. Бобров \\ Горный институт УрО РАН, г. Пермь
}

\begin{abstract}
Аннотация. Высокая степень изученности процесса газодинамических явлений не вызывает сомнений, но, к сожалению, в настоящее время для условий калийных рудников на Верхнекамском месторождении калийно-магниевых солей отсутствует понимание механизма образования очагов газодинамических явлений в складчатых структурах. Анализ геологических и горнотехнических условий проявления газодинамических явлений позволил выявить приуроченность очагов газодинамических явлений к зонам развития интенсивной складчатости и антиклинальным складкам в калийных пластах. Таким образом, представленная проблема образования очагов газодинамических явлений в складчатых структурах изучена недостаточно глубоко, и ее решение приобретает особую актуальность, имеет большое теоретическое и практическое значение. Разработан механизм образования очагов газодинамических явлений в зонах складчатых структур калийных пластов, заключающийся в формировании «газового» коллектора и области пониженной прочности соляных пород при образовании трещин складок и трещин отслоений с последующей фильтрацией свободного газа в образовавшиеся в складках пустоты из вмещающегося массива и сохранение образовавшихся газонасыщенных областей в соляном породном массиве как квазиизолированных систем пустот длительное геологическое время при условии превышения величиной начального градиента давления величины давления газа на контуре очага. Представленная совокупность трещин и расслоений, образовавшихся в пределах сформировавшейся складчатой структуры и заполненных свободным газом под давлением, представляет собой потенциальный очаг газодинамического явления, сформировавшийся в соляном породном массиве. Разработана модельная схема механизма образования очагов газодинамических явлений в складчатых структурах калийных пластов. Разработанный механизм образования очагов газодинамических явлений и его модельная схема приведут к повышению безопасности ведения горных работ в условиях складчатого строения породного массива на рудниках Верхнекамском месторождении калийно-магниевых солей за счет целенаправленного применения профилактических мероприятий.
\end{abstract}


Ключевые слова: Верхнекамское месторождение калийно-магниевых солей, газодинамическое явление, калийные пласты, складчатые структуры, антиклинальные складки третьего порядка, трещины складок, трещины отслоений, давление газа, градиент давления, фильтрация газа.

\section{Введение}

В настоящее время степень изученности процесса газодинамических явлений является достаточно высокой, однако газодинамические явления в калийных рудниках на Верхнекамском месторождении калийно-магниевых солей продолжают происходить, угрожая жизни шахтеров и нарушая ритмичность работы рудников [1-11]. Одним из актуальных вопросов повышения безопасности ведения горных работ на калийных пластах является прогнозирование и предотвращение газодинамических явлений в складчатых структурах разрабатываемых калийных пластов [12-16]. Для разработки научно обоснованных методов прогнозирования и способов предотвращения газодинамических явлений, происходящих при ведении горных работ в складчатых структурах, необходимо разработать механизм образования очагов газодинамических явлений в таких зонах. В этой связи целью данных исследований является разработка модельной схемы механизма формирования очагов газодинамических явлений в условиях складчатого массива калийных пластов, позволяющих повысить эффективность и безопасность ведения горных работ.

Основная идея работы заключается в использовании приуроченности очагов газодинамических явлений к зонам интенсивной складчатости и антиклинальным складкам в соляном породном массиве. Основные задачи выполняемой работы: выполнить анализ геологических и горнотехнических условий проявления газодинамических явлений в условиях складчатого массива; разработать механизм формирования очагов газодинамических явлений в складчатых структурах калийных пластов; разработать модельную схему механизма формирования очагов газодинамических явлений в складчатых структурах калийных пластов.

\section{Анализ геологических и горнотехнических условий проявления газодинамических явлений в условиях складчатого соляного массива}

Общая структура Верхнекамского месторождения калийно-магниевых солей по кровле солей проявляется чередованием крупных (не менее нескольких километров в плане) положительных (поднятия, купола) и отрицательных (синклинали, прогибы, мульды, впадины) локальных тектонических структур, которые прослеживаются и внутри солей.

Внутрисоляные деформации комплексов - это преимущественно складчатые дислокации. Складки отличаются не только по размерам, но и глубине распространения. Для вскрытой подземными горными выработками части разреза соляной толщи на Верхнекамском месторождении выделяют 4 порядка складок [17].

Складки первого порядка это внутрипластовые, внутрислоевые складчатости амплитудой до нескольких сантиметров или дециметров. Охватывают годовые прослои внутри пластов и слоев в ядрах антиклинальных складок последующих порядков. Высота складок этого порядка от 3-5 см до 6-9 дм, ширина до 1 м, длина до 5-7 м. Амплитуда отдельных лежачих внутрислоевых складок до 1,5-2,0 м. Складки данного порядка сопровождаются обычным, спокойным выделением, не приводящим к газодинамическим явлениям.

Складки второго порядка охватывают отдельные слои и пласты. Высота складок 0,52,0 м, ширина от 3-7 до 10-15 м, длина 10-40 м, амплитуда отдельных лежачих складок, 
образуемых слоями каменной соли в калийных пластах, до 4-6 м. Таким складкам так же присуще газовыделение, но масштаб его не значителен.

К третьему порядку относятся складки, охватывающие пласты внутри соляной толщи от пласта КрIII до пласта В. При этом размеры складок составляют: высота от 3 м до 12 м, ширина от 20 м до 100 м, длина - до 370 м. При этом от пласта КрIII к пласту В они становятся более асимметричными, высота их несколько увеличивается, а ширина уменьшается. В вертикальном разрезе своды складок вышележащих пластов смещены на запад по отношению к залегающим ниже пластам. Высота складок 3-12 м, ширина от 20-30 до 100 м, длина до 300 м (отдельных складок - до 370 м). По вертикальному разрезу размеры складок 3-го порядка меняются следующим образом: по пластам КрIII и КрII высота складок 3-8 м при ширине 40-100 м, по пластам КрI и АБ высота 5-10 м при ширине 30-80 м, по пласту В карналлитового состава высота складок 6-12 м при ширине 20-50 м [18]. В пределах антиклинальных складок третьего порядка в процессе складкообразования образуются открытые трещины, а по наиболее слабым слоям галопелитов образуются расслоения. Согласные и секущие трещины, образующиеся в замковых частях антиклинальных складок третьего порядка и заполненные свободным газом, в большинстве случаев являются очагами ГДЯ при отработке пласта АБ.

В качестве примера приведем газодинамическое явление в виде внезапного выброса соли и газа из забоя, произошедшее 18 февраля 2010 г. в руднике БКПРУ-2 ПАО «Уралкалий» на 9 восточной панели при отработке второго хода тупиковой очистной камеры № 192 на пласте АБ в процессе отбойки руды (рис. 1).

Анализ геологических причин внезапного выброса соли и газа в левом ходу камеры № 192 проводился на основании визуального обследования геологического строения пласта АБ в правом и левом ходах, забоя левого хода и полости выброса соли и газа. На основании обследования установлено, что камерой № 192 вскрыто локальное погружение поверхности пласта АБ и его субмеридиональный перегиб высотой около 5 м. В целом анализ локальных геологических условий проявления внезапного выброса соли и газа показал, что его геологической причиной является очаговое скопление свободных газов, приуроченное к складчатому перегибу, в котором активно проявлялись эпигенетические процессы: дробления, трещинообразования и перекристаллизации солей, растяжения и расслоения глинистых прослойков, благоприятных для мобилизации и аккумуляции свободных газов.
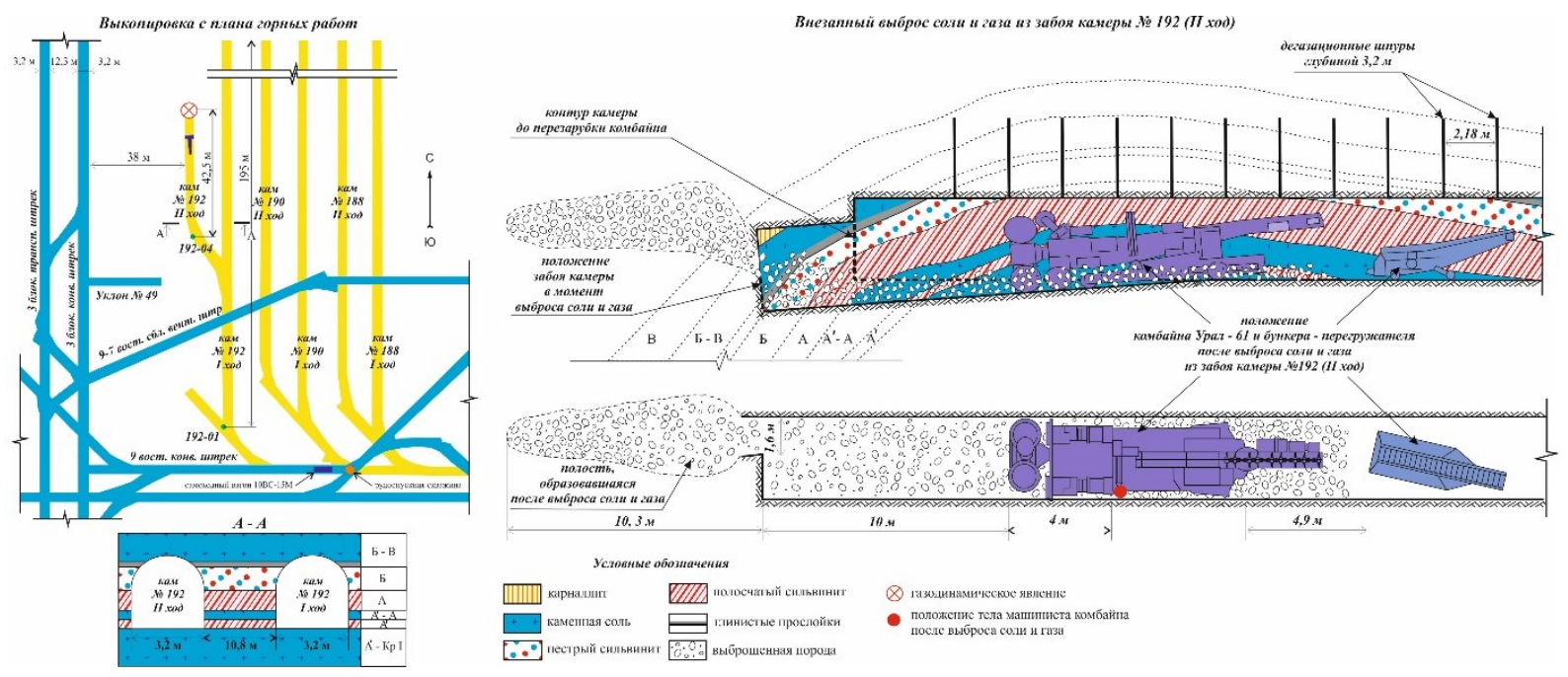

Рис. 1. Внезапный выброс соли и газа из забоя (рудник БКПРУ-2, пласт АБ, 9-я восточная панель, левый ход камеры № 192) 
Анализ горнотехнических условий внезапного выброса соли и газа в камере № 192 показал, что в месте выброса породы и газа наблюдается резкое погружение пласта АБ. При этом в процессе проходки комбайном «Урал-61» № 28 был вскрыт (подрезан) пласт каменной соли Б-В, выполняющий функцию защитной пачки, на мощность примерно 1,2-1,4 м. Исходя из «согласного» залегания пластов АБ и В, можно предположить, что и пласт В также резко погрузился в данном месте и практически оказался не в кровле, а в забое выработки. Под действием давления газа в очаговом скоплении (собственно очаге выброса) защитная пачка, представленная частью пласта Б-В мощностью 0,4 м, разрушилась, выбросоопасные породы обнажились, и далее развился собственно выброс породы и газа из груди забоя камеры. При выбросе под действием газопородного потока комбайн был отброшен от забоя на расстояние до 10 м. Здесь следует отметить весьма важный технологический момент. Применение комбайна с «жестким» исполнительным органом и ограждающим щитом не позволяет контролировать поведение пласта на небольших расстояниях проходки (1-2 м). При резком погружении пласта машинист комбайна не успевает среагировать на изменение геологических условий. Это всегда будет приводить к подрубке защитной пачки - пласта каменной соли Б-В и в отдельных случаях к вскрытию выбросоопасного пласта В.

Следующий 4-й порядок складок (выделен только в пределах Березниковского поднятия), к которому отнесены линейные синклинальные складки, примыкающие к зонам каменной соли сильвинитовых пластов в пределах террасообразной структурной площадки. Размеры складок: длина 700-1300 м, ширина 120-250 м, высота 20-30 м. Складки 4-го порядка, как и складки 3-го порядка, охватывают серию пластов внутри соляной толщи - прослеживаются по всем вскрытым калийным пластам.

Все складки внутри соляной толщи, независимо от их порядка и положения в пределах поднятий, имеют одну общую характерную черту: все они однообразно асимметрично построены - западные крылья у них более крутые, чем восточные, а осевые поверхности опрокинуты в той или иной степени только в одном направлении - на запад. В плане складки сочетаются кулисообразно. Длинные оси складок в общем параллельны между собой и осям соляных поднятий.

\section{Модель механизма образования очагов газодинамических явлений в складчатых структурах калийных пластов}

Статистический анализ геологических условий проявления ГДЯ при отработке пласта АБ показал, что к антиклинальным складкам третьего порядка приурочено более $70 \%$ от их общего числа. В этой связи прогнозирование зон, опасных по газодинамическим явлениям, на основе структурно-тектонического анализа является актуальной задачей.

Формирование крупных складок - складок 3-го порядка - происходит под действием региональных тектонических сил и на начальном этапе характеризуется квазиоднородным напряженным состоянием. Данное состояние характеризуется горизонтальным залеганием соляных пород и наличием в массиве свободных газов под давлением $\mathrm{P}_{\text {м }}$ (рис. 2).

По мере развития дислокации и особенно на конечных этапах ее формирования существенное изменение геометрии пластов ведет к появлению локальных неоднородностей поля напряжений. Неизбежной реакцией на эту флуктуацию напряжений являются: изменение структурно-текстурных особенностей пород, возникновение новых зон микротрещин и другие процессы, обусловливающие изменение физико-механических свойств пород [19].

В настоящее же время анализ морфонологии и возможных механизмов формирования складок различного порядка показал, что соляная залежь соликамской впадины представляет собой тектонически компенсированную мульду, осложнённую складками разного масштаба, морфологии и природы [20]. Так д.г.-м.н. И.И. Чайковский в своих работах отмечает 
огромную роль послойных срывов при формировании складчатых структур на Верхнекамском месторождении калийно-магниевых солей. Данный факт отражает послойный сдвиг и скольжение, реализуемые по многим дискретным плоскостям [21].

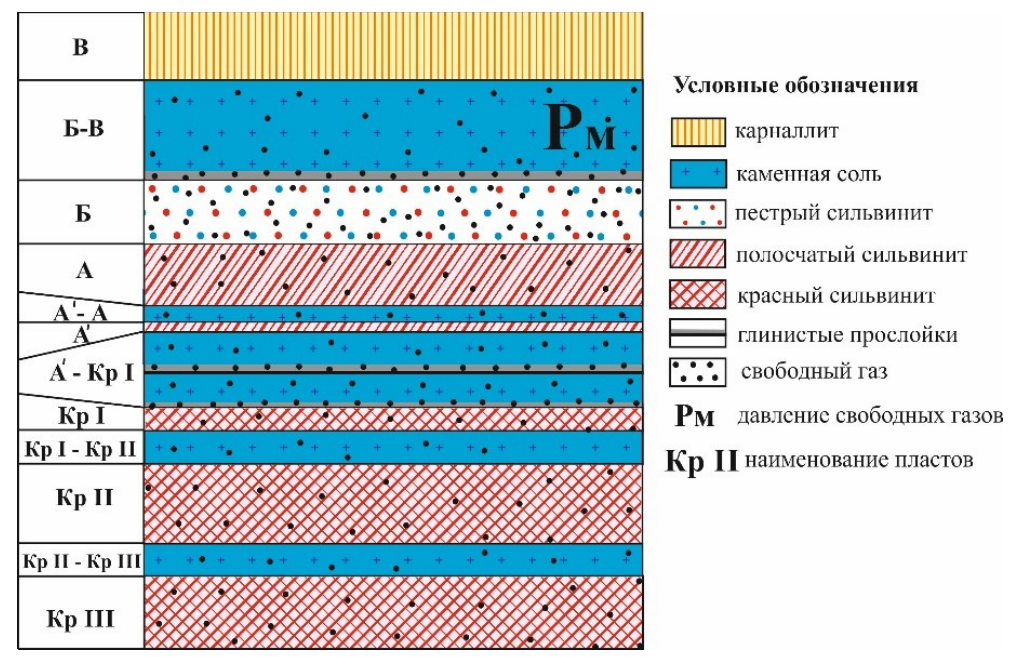

Рис. 2. Исходное состояние породного массива на Верхнекамском месторождении калийно-магниевых солей

Таким образом, рассматриваемые в работе антиклинальные складки третьего порядка представлены симметричными складками с пологим сводом или ассиметричными угловатыми и коробчатыми, которые претерпели продольное сжатие в сочетании с послойным сдвигом и срывом. Передача региональных напряжений по всей калийной залежи происходит из-за ее флюидоподобного состояния, т.е. складчатость Верхнекамского месторождения представляет собой кондиагенетическое образование [22].

Из геологических факторов в формировании зон, опасных по газодинамическим явлениям, играют роль зоны трещиноватости и расслоений по наиболее слабым галопелитовым прослойкам (рис. 3, 4).

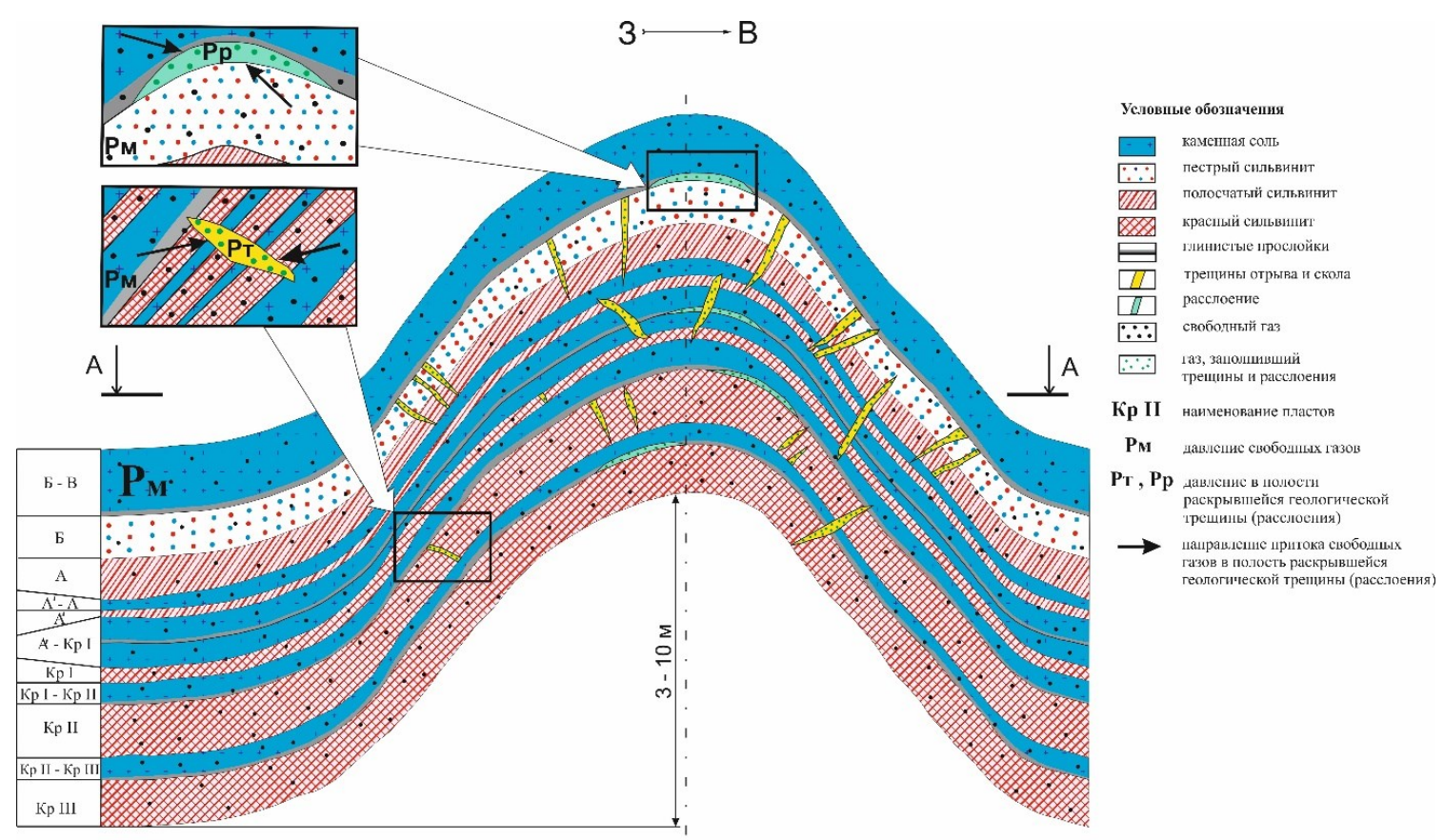

Рис. 3. Модельная схема механизма формирования очага газодинамического явления в пределах складчатых структур калийных пластов 
Ввиду тектонических процессов и процессов складкообразования происходит раскрытие трещин двух видов [23]. Первая группа - трещины складок, которые представлены секущими трещинами. По ориентировки к осям складок делятся на три группы поперечные, продольные и диагональные. Так как антиклинальные складки на Верхнекамском месторождении имеют преимущественную субмеридиональную ориентацию, то продольные секущие трещины обычно имеют так же субмеридиональное простирание, поперечные - субширотное, а диагональные направлены либо с севера на запад либо с запада на восток. Продольные трещины развиты главным образом на соляных поднятиях и обычно приурочены к замковым частям антиклинальных и синклинальных складок. Они обнаружены в интервале пластов от А до Г. Длина трещин колеблется в интервале 0,5-20,0 м, зияние - 2,0-20 см. Поперечные трещины являются крутопадающими (80-90 ), их длина 1-16 м, а высота может достигать 2 м. Раскрытие поперечных трещин колеблется от 1 до 8 см. Диагональные секущие трещины наиболее редко встречающийся вид из трех. Как правило, они встречаются в серии кулисообразных трещин длиной от 0,5 до10 м, раскрытие не превышает 1 см [17].

Вторые из представленных трещин - трещины отслоений. Наиболее часто встречаются на куполах складок различных порядков, сопутствуют формированию складок продольного сжатия. Длина трещин достигает нескольких метров, а величина зияния обычно первые сантиметры, в отдельных случаях может достигать 20 см. Трещины отслоений, как правило, заполнены газом, выделение которого при вскрытии может продолжаться в течение нескольких суток. Реже трещины данного типа могут быть заполнены внутрисолевыми рассолами бурового цвета.

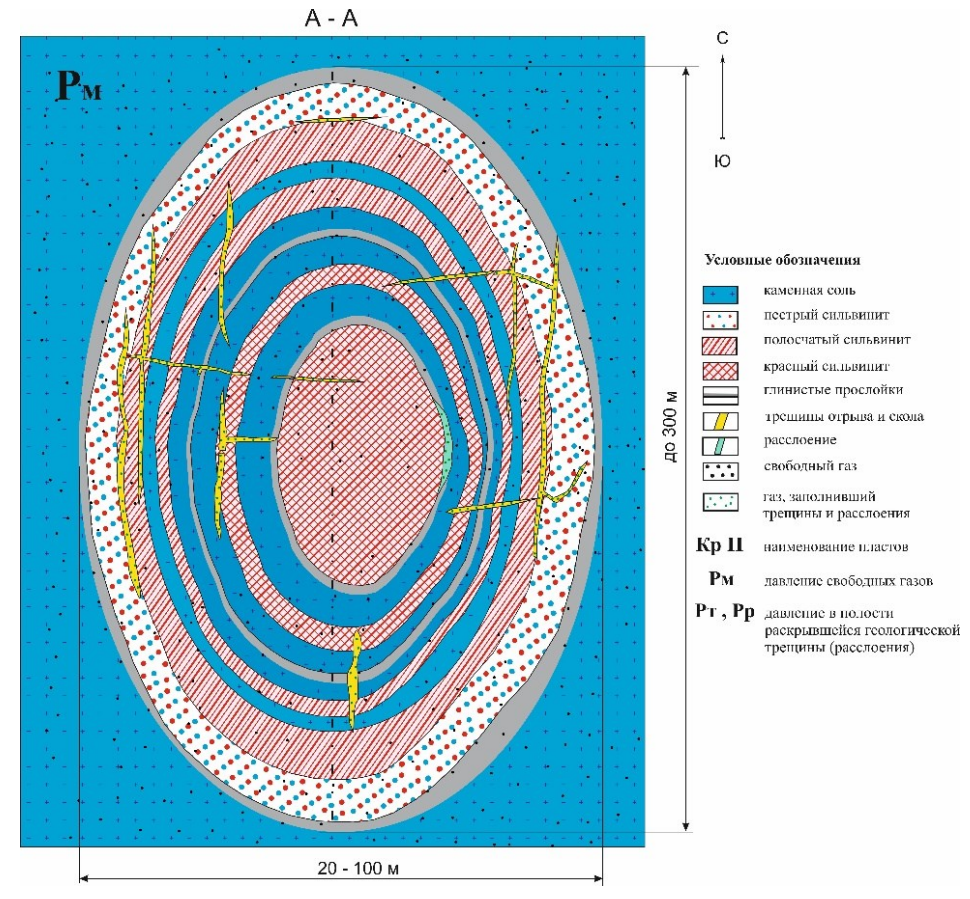

Рис. 4. Разрез по линии А-А складчатой структуры, представленной на рисунке 2

В процессе формирования в калийных пластах зон, опасных по газодинамическим явлениям, складчатые структуры несут две функции: во-первых, они формируют «газовый коллектор» и зону пониженной прочности пород, во-вторых, собирают газ с окружающих участков пласта по принципу «вакуумного насоса» [22]. Поэтому очевидно, что механизм формирования складчатых зон, опасных по газодинамическим явлениям, в калийных пластах связан с освобождением части связанных газов под воздействием деформационных процессов и последующей аккумуляцией уже свободных газов в трещинах и расслоениях по галопелитовым прослойкам в складках (рис. 3,4 ). 
Очевидно, что в процессе складкообразования и образования в пределах складки систем трещин и расслоений внутри области соляных пород, содержащей свободные газы, возникнет перепад давления - газовая депрессия (геологический вакуум), величина которой будет определяться соотношением давление свободных газов на контуре раскрывшейся геологической трещины и давления в полости раскрывшейся геологической трещины [23]:

$$
\Delta \mathrm{P}=\mathrm{P}_{\mathrm{M}}-\mathrm{P}_{\mathrm{T}}, \Delta \mathrm{P}=\mathrm{P}_{\mathrm{M}}-\mathrm{P}_{\mathrm{p}},
$$

где $\mathrm{P}_{\mathrm{M}}$ - давление свободных газов на контуре раскрывшейся геологической трещины; $\mathrm{P}_{\mathrm{T}}$ - давление в полости раскрывшейся геологической трещины; $\mathrm{P}_{\mathrm{p}}-$ давление в полости расслоения.

Известно, что свободные газы в соляном породном массиве находятся макропорах, микротрещинах, трещинах, на границах зерен, в слоях и прослойках соленосных глин, на контактах разностей соляных пород. Поэтому при превышении давления свободных газов на контуре раскрывающейся геологической трещины (расслоения) $\mathrm{P}_{\mathrm{M}}$ над давлением в полости данной трещины (расслоения) $\mathrm{P}_{\mathrm{T}}\left(\mathrm{P}_{\mathrm{p}}\right)$ по флюидопроводникам начнется приток свободных газов из окружающего соляного породного массива в трещину или расслоение. Флюидопроводниками будем считать наиболее слабые контакты калийной залежи - слои и прослойки соленосных глин, микротрещиноватость пород и границы зерен. Таким образом, раскрывшаяся трещина и расслоение будут концентрировать в себе свободные газы, а замкнутость полостей трещин и расслоений будет препятствовать транзиту свободных газов как вверх по геологическому разрезу, так и в латеральном направлении.

В конечном итоге совокупность трещин и расслоений, образовавшихся в пределах сформировавшейся складчатой структуры и заполненных свободным газом под давлением, будет представлять собой потенциальный очаг газодинамического явления, сформировавшийся в соляном породном массиве.

\section{Выводы}

Исследование геологических условий проявления газодинамических явлений в условиях Верхнекамского месторождения калийных солей позволяет сделать следующие выводы.

1. Существующие представления о механизмах образования очагов газодинамических явлений не отражают полноту процессов в условиях складчатого массива. Механизм образования очагов газодинамических явлений в условиях складчатого строения калийных пластов в настоящее время не разработан.

2. Формирование крупных складок происходит под действием региональных тектонических сил на стадии дигенеза осадков и на начальном этапе характеризуется квазиоднородным напряженным состоянием. На конечном этапе формирования складчатых структур изменение геометрии пластов ведет к появлению локальных неоднородностей поля напряжений.

3. Неизбежной реакцией на флуктуации напряжений в процессе складкообразования являются изменение текстурно-структурных особенностей пород, возникновение новых зон трещин (трещины складок, трещины отслоения и расслоений по наименее прочным галопелитовым прослойкам).

4. При образовании трещин складок и трещин отслоений происходит формирование «газового» коллектора и области пониженной прочности соляных пород с последующей фильтрацией свободного газа в образовавшиеся в складках пустоты из вмещающегося массива и сохранение образовавшихся газонасыщенных областей в соляном породном массиве как квазиизолированных систем пустот длительное геологическое время при условии превышения величиной начального градиента давления величины давления газа на контуре очага. 
5. Совокупность трещин и расслоений, образовавшихся в пределах сформировавшейся складчатой структуры и заполненных свободным газом под давлением, будет представлять собой потенциальный очаг газодинамического явления, сформировавшийся в соляном породном массиве.

\author{
Работа выполнена при поддержке Программ ФНИ, \\ проекты № 0422-2019-0145-C-01 и № 0422-2019-0007-С-01.
}

\title{
БИБЛИОГРАФИЧЕСКИЙ СПИСОК
}

1. Андрейко С.С., Иванов О.В., Литвиновская Н.А. Прогнозирование и предотвращение газодинамических явлений из почвы при проходке подготовительных выработок в подработанном массиве соляных пород. - Пермь: изд-во ПНИПУ, 2015. - 159 с.

2. Андрейко С.С., Иванов О.В., Нестеров Е.А. Борьба с газодинамическими явлениями при разработке Верхнекамского и Старобинского месторождений калийных солей // Науч. исслед. и инновации. 2009. - T. 3, № 4. - С. 34-37.

3. Андрейко С.С., Литвиновская Н.А. Локальный прогноз зон, опасных по газодинамическим явлениям из почвы горных выработок пласта АБ на южной части шахтного поля БКПРУ -4 Верхнекамского месторождения калийных солей // Горный информационно-аналитический бюллетень (научнотехнический журнал). - 2013. - № 4. - С. 205-211.

4. Andreiko S., Baryakh A., Lobanov S., Fedoseev A. Geo mechanical Estimation of Danger of Gas-Dynamic Failure During Potash Deposits Mining / // ISRM European Rock Mechanics Symposium (EUROCK). 2017. - V. 191. - P. 954-961.

5. Барях А.Б., Андрейко С.С., Федосеев А.К. О механизме локализации очагов газодинамических явлений в почве сильвинитовых пластов // Вестн. ПНИПУ: Геология. Нефтегазовое и горное дело. - 2017. - T. 16, № 3.- C. 247-254. DOI: 10.15593/2224-9923/2017.3.5.

6. Андрейко С.С., Лукьянец Е.В., Литвиновская Н.А., Нестеров Е.А., Бобров Д.А., Поляков А.Л., Лутович Е.А. Параметры профилактической дегазации пород почвы горных выработок при слоевой отработке третьего калийного пласта на рудниках ОАО «Беларуськалий» // Вестн. ПНИПУ: Геология. Нефтегазовое и горное дело. - 2017. - Т. 16, № 3.- С. 280-290. DOI: 10.15593/22249923/2017.3.9.

7. Андрейко С.С., Мальцев В.М., Аникин В.В., Жихарев С.Я. Обоснование безопасных параметров буровзрывной отработки сильвинитовых пластов некондиционной мощности совместно с комбайновой выемкой кондиционных пластов на рудниках Верхнекамского месторождения калийно-магниевых солей // Вестн. ПНИПУ: Геология. Нефтегазовое и горное дело. - 2017. - Т. 16, № 4.- С. 357-369. DOI: $10.15593 / 2224-9923 / 2017.4 .7$.

8. Andreyko S.S., Lyalina T.A. Rockburst from floors // Soils and Rocks. - 2019. - V. 42, 1. - P. 77-82. DOI: $10.28927 /$ SR.421077.

9. Андрейко С.С. Современное состояние проблемы газодинамических явлений на действующих и вводимых в эксплуатацию калийных рудниках // Горное эхо. - 2019. - № 2 (75). - С.82-89.

10. Андрейко С.С., Иванов О.В., Нестеров Е.А. Исследование способов предотвращения внезапных отжимов призабойной части соляных пород // Горный журнал. - 2018. - № 6. - C.30-34. DOI: 10.17580/gzh.2018.06.06.

11. Андрейко С.С., Литвиновская Н.А., Сиренко Ю.Г., Чаянов А.Б. Предотвращение газодинамических явлений из почвы горных выработок при различных вариантах столбовой системы разработки на рудниках ОАО «Беларуськалий» // Горн. журн. - 2018. - № 8. - С. 29-33.

12. Андрейко С.С., Зверева Е.В. Прогнозирование зон, опасных по газодинамическим явлениям, на шахтном поле рудника СКРУ-3 ОАО «Уралкалий» на основе структурно-тектонического анализа строения пласта АБ // Вестн. ПНИПУ: Геология. Нефтегазовое и горное дело. - 2013. - Т. 12, № 7. - С. 79-88.

13. Лукьянец Е.В. Безопасное ведение подготовительных и очистных горных работ по пласту АБ в выработках ПАО «Уралкалий», опасных по газодинамическим явлениям, на основе структурнотектонического анализа строения // Проблемы разработки месторождений углеводородных и рудных полезных ископаемых.. - 2015.- № 1. - С. 243-247.

14. Андрейко С.С., Литвиновская Н.А. Modeling sudden failure of floor of underground excavations in undermined salt rock mass. - Eurasian Mining. Moscow, Tiso Print, 2015, №2 (24), P. 15-17.

15. Андрейко С.С. Анализ структурно-тектонических условий проявления газодинамических явлений в надвиговых и сдвиговых зонах на шахтных полях рудников БКПРУ-2 и БКПРУ-4//Стратегия и процессы освоения георесурсов: сб. науч. тр. - Пермь: ГИ УрО РАН.-2015.- Вып. 13.-С. 225-228. 
16. Andreiko S.S., Litvinovskaya N.A., Lyalina T.A. Control of gas-dynamic processes in floor rock mass in sylvinite bed AB of the Upper Kama Potassium Salt Deposit // Gornyi Zhurnal. - 2015. - № 4. - P. 89-92. DOI: $10.17580 /$ gzh.2015.04.16.

17. Кудряшов А.И. Верхнекамское месторождение солей. - 2-изд., перераб. - М.: Эпсилон Плюс, 2013. $368 \mathrm{c}$.

18. Копнин В.И., Коротаев М.А. Стратификация соляной толщи Верхнекамского местрождения калийных солей // Строение и условия формирования месторождений калийных солей. - Новосибирск, 1981 - С. 79-94.

19. Петротектонические основы безопасной эксплуатации Верхнекамского месторождения калийномагниевых солей / под ред. Н.М. Джиноридзе. - СПб; Соликамск, 2000. - 400 с.

20. Лукьянец Е.В. Анализ структурно-тектонических условий проявления газодинамических явлений в надвиговых и сдвиговых зонах на шахтном поле рудника БКПРУ-2 // Стратегия и процессы освоения георесурсов: сб. науч. тр. Вып. 16 / ГИ УрО РАН. - Пермь, 2018. - С. 329-332. DOI: 10.7242/gdsp.2018.16.87

21. Чайковский И.И. Разноранговость и природа пликативных структур в сильвинитах Верхнекамского месторождения // Стратегия и процессы освоения георесурсов: сб. науч. тр. Вып. 9 / ГИ УрО РАН. Пермь, 2011. - С. 3-6.

22. Копнин В.И., Пшеничников А.Г. Структурно-тектонические условия газодинамических явлений на Березниковских калийных рудниках и вопросы прогнозирования выбросоопасных зон // Разработка калийных месторождений: Межвуз. сб. науч. тр. -Пермь, 1984. - С.96-99.

23. Нестеров Е.А. Исследование и разработка методов прогнозирования и способов предотвращения внезапных отжимов призабойной части пород при отработке калийных пластов: автореф. дис. ... к.т.н.; 25.00.20 / Нестеров Егор Анатольевич. - Пермь, 2016. - 19 с.

\title{
РЕЗУЛЬТАТЫ ОПЫТНО-ПРОМЫШЛЕННЫХ ИСПЫТАНИЙ ПРОХОДКИ ПОДГОТОВИТЕЛЬНЫХ ВЫРАБОТОК В ВЫБРОСООПАСНЫХ ДОЛОМИТОВЫХ ПОРОДАХ
}

\author{
Е.А. Нестеров \\ Горный институт УрО РАН, г. Пермь
}

\begin{abstract}
Аннотация: Развитие горных работ на руднике «Интернациональный» предусматривает проходку подготовительных горных выработок на глубинах более 1000 м. Известно, что на таких глубинах вмещающие породы подвержены высокому горному давлению и, как показывает практика ведения горных работ на руднике «Интернациональный», газонасыщены. Высокое горное давление, газонасыщенность, газодинамические характеристики и физико-механические свойства вмещающих пород предопределяют склонность этих пород к газодинамическим явлениям в процессе проходки подготовительных выработок. В связи с этим фактом при проходке подготовительных выработок на руднике «Интернациональный» на больших глубинах появилась настоятельная необходимость в разработке безопасной технологии проходки горных выработок во вмещающих доломитовых породах, склонных к выбросам породы и газа.

В статье представлен вариант технологии проходки подготовительных выработок во вмещающих доломитовых породах, а также результаты оценки эффективности передового торпедирования пород при проходке горных выработок на стадии опытно-промышленных испытаний.
\end{abstract}

Ключевые слова: газодинамические явления, выбросы породы и газа, передовое торпедирование, опытно-промышленные исследования, дегазация, газоносность.

В настоящее время на руднике «Интернациональный» АК «Алроса» для вскрытия более глубоких горизонтов проходят ряд горных выработок во вмещающих доломитовых породах. Проходка горных выработок осуществляется буровзрывным способом. Как известно, с увеличением глубины разработки увеличивается горное давление на выработки, ухудшаются условия разработки по газовому фактору, увеличивается вероятность появления динамических разрушений горных пород [1-20]. Все это в полной мере проявляется на руднике «Интернациональный». 